\title{
Administrative Management of Improvement Processes of Socio-Cultural Forms Based on Principles of Sustainable Development of Education
}

\author{
Nataliia M. Ridei \\ National Pedagogical Dragomanov University \\ Nataliia M. Tytova \\ National Pedagogical Dragomanov University \\ Oleg A. Diegtiar \\ Vasyl Stefanyk Precarpathian National University \\ Dmytro H. Pavlenko \\ National Pedagogical Dragomanov University \\ Oleksandr M. Slabetskyi \\ National Pedagogical Dragomanov University
}

The theoretical-methodical and practical foundations of improvement of administrative management processes on the principles of sustainable development of education are studied in the article. Main problems in the management of the education system in Ukraine were identified. The stages of improvement of the education management process of Ukraine based on continuity were identified and proposals for the modernization of each stage were provided. It is proved that administrative management should be carried out based on innovative strategies under the principles of sustainable development by creating the latest systems of educational projects and monitoring, developing a model of public administration, strengthening the role and interaction of educational policy actors based on the provision that the individual, society and the state are fully equal actors and partner. A complex of measures is proposed to improve the administrative management of education to ensure the creation of a flexible, focused, effective system, a focus on meeting the needs of the country and the needs of the individual.

Keywords: socio-cultural forms, education, theatres, libraries, cultural heritage

\section{INTRODUCTION}

Significant changes in the modern system of views on the place and role of socio-cultural forms underline its importance for present and future generations. Such changes are possible only in the context of the implementation of effective administrative management of the development and improvement of these forms, which will contribute to the preservation of the cultural heritage of cities, regions, and Ukraine 
as a whole, as well as to improving the quality of the provision of educational services by educational institutions. World experience shows that the problems of sustainable development of socio-cultural forms, their financing and their role for society, and, most importantly, their management are common to all states of Europe and the world, regardless of their level of development and the existing educational, scientific and cultural heritage. It should be noted that the issue of adequate training of qualified personnel is particularly acute as a basis for improving the complex of socio-cultural forms through scientific, methodological, and practical studies to develop new administrative mechanisms and improve existing ones.

Despite the importance of education and culture for society, the development and engineering of sociocultural forms at the levels of state and municipal administration are often not included as a separate area of sustainable development of the state but are considered in conjunction with others. During the political, financial, economic, and social crisis of recent times, which is taking place in Ukraine, the situation arises that theoretical, methodological, and practical models for the sustainable development of socio-cultural forms and their role in socio-economic growth are not being developed, despite the urgent relevance of this problem. Therefore, the development of effective and realistic solutions to the problems of development, financing, self-financing, the creation of new and the preservation of existing jobs in the education and culture on the basis of effective administrative management is the key to maintaining and restoring the educational, scientific and cultural heritage of the state and the further socio-cultural development of society in the long term.

Many diverse scientific works of famous foreign and domestic economists are devoted to the problems of improving the processes of administrative management of socio-cultural forms on the principles of sustainable development of education, namely: A. Pukhtetskaya, V.K. Kolpakov, K.O. Kolesnykova, T.B. Semenchuk, R.S. Melnyk, A.V. Andrieiev, E. Kakiuchi, M. Muthu, Y. Romanenko, V.A. Mishchenko et al., T. Burmaka, N. Orlova, O. Nepomnyashchyy and others, A.P. Lelechenko, O.Y. Lebedinska, T.M. Derun, O.V. Berdanova, O.A. Diegtiar and others. However, despite the theoretical, methodological, and practical results obtained, the issues of the relationship between socio-cultural forms and the sustainable development of education remain undefined and insufficiently investigated.

The general purpose of the article is to develop a recommendation on the practical implementation of directions for improving the administrative management of socio-cultural forms on the principles of sustainable development of education. To achieve a specified purpose, the following problems are being addressed in the article:

- to clarify the concept of "administrative management" for the study of socio-cultural forms;

- to define the category of "socio-cultural forms" in the context of sustainable development;

- to systematize the main elements of socio-cultural forms and make recommendations for improving their administrative management;

- to prove the generalizing importance of effective education administration for the sustainable development of other socio-cultural forms;

- to analyze the main problems of education management, systematize the stages of improvement of the education management process, and propose a complex of measures to modernize the administrative management of education of Ukraine in the current conditions and in the perspective of development.

\section{THE CONCEPT OF “ADMINISTRATIVE MABAGEMENT” AND ITS MAIN CHARACTERISTICS}

For an effective study of the processes of improving socio-cultural forms, first of all, it is necessary to clarify the definition of the concept of "administrative management" and provide the author's definition taking into account the peculiarities inherent in the educational and cultural space of Ukraine. Among the opinions of well-known scientists on the definition of the essence and elements of the concept of "administrative management", the following can be distinguished (Table 1). 
TABLE 1

BASIC DEFINITIONS OF “ADMINISTRATIVE MANAGEMENT"

\begin{tabular}{|c|c|c|}
\hline No. & $\begin{array}{l}\text { Author of the } \\
\text { definition }\end{array}$ & The main essence of the definition \\
\hline 1 & A. Pukhtetska & $\begin{array}{l}\text { A complex of bodies, institutions and organizations carrying out } \\
\text { administrative functions, administrative activities carried out by this } \\
\text { administration in the interests of society, as well as as the sphere of public } \\
\text { sector management by the same public administration }\end{array}$ \\
\hline 2. & V.K. Kolpakov & $\begin{array}{l}\text { The possibility of giving subjects the choice of the desired and beneficial } \\
\text { option for them, aimed primarily at uniting and coordinating the efforts of } \\
\text { people, state bodies, institutions, enterprises, and organizations of various } \\
\text { forms of ownership to solve political, economic, scientific, technical and } \\
\text { social problems }\end{array}$ \\
\hline 3 & K.O. Kolesnykova & $\begin{array}{l}\text { A management component that is a procedure for implementing solutions } \\
\text { implemented in the management system }\end{array}$ \\
\hline 4 & T.B. Semenchuk & $\begin{array}{l}\text { Activities of public administration entities regulated by laws and other } \\
\text { regulatory legal acts aimed at implementing laws and other legislation by } \\
\text { making administrative decisions and providing administrative services } \\
\text { established by laws }\end{array}$ \\
\hline 5 & R.S. Melnyk & $\begin{array}{l}\text { A detailed description of the actions to be consistent, in an appropriate } \\
\text { manner, and with the use of specific methods and techniques, which are } \\
\text { carried out by the administrative management entity (organization or } \\
\text { concrete official) in order to achieve a certain goal. Procedures for } \\
\text { implementing administrative management regulating the direction and } \\
\text { sequence of actions of employees are clearly specified in the technology, } \\
\text { exclude the use of inefficient techniques, provide managers with } \\
\text { confidence regarding the rationality of actions of subordinates and } \\
\text { obtaining the desired result }\end{array}$ \\
\hline 6 & $\begin{array}{l}\text { V.V. Korzhenko, } \\
\text { N.M. Meltiukhova }\end{array}$ & $\begin{array}{l}\text { This is a targeted interaction of the administration with legal entities and } \\
\text { individuals to ensure the implementation of laws and by-laws. In a narrow } \\
\text { sense, administrative management is related to the executive branch of } \\
\text { government and is considered as a professional activity of public servants, } \\
\text { which covers all activities aimed at implementing government decisions, } \\
\text { studying, developing, and implementing government policies }\end{array}$ \\
\hline 7 & A.V. Andrieiev & $\begin{array}{l}\text { Activities of the public administration to satisfy the general public interests } \\
\text { of society. Administrative management is more consistent with the new } \\
\text { "human-centric" doctrine of administrative law and corresponds to the } \\
\text { modern realities of the practical activities of the state in education and } \\
\text { culture }\end{array}$ \\
\hline
\end{tabular}

Thus, by summarizing the definitions provided in Table 1, it is possible to develop a refined author's vision of the content of the "administrative management" category for the needs of research on sociocultural forms, namely - this is a systematic, organized, administrative activity of state and municipal authorities regulated by laws and regulatory acts, which is aimed at supporting, improving and developing the organizational structure of socio-cultural forms, planning, preparing, forming and implementing the necessary management decisions by the introduction of the documentary, information, personnel and psychological support for their functioning to achieve public interest goals and tasks in the educational, cultural and scientific sphere. 
Summarizing the essence of the "administrative management" category, it is appropriate to identify the main elements that are included in the structure of socio-cultural forms and provide proposals for improving the process of their management in the modern conditions of Ukraine. Thus, socio-cultural forms in the context of sustainable development are the embodiment of a complex of material and spiritual values, which reflect the constant creative activity of society in the development of the environment, in the course of historical development, and the coverage of the nature of human life through research by addressing its individual spheres, namely, educational, artistic, religious, scientific, political, moral and legal, etc.. It should be noted that the basis for the effective management of processes for improving socio-cultural forms is, in our opinion, education at all levels of its implementation and functioning. Therefore, the main focus of our study will be to provide proposals for modernizing this element of socio-cultural forms. However, it should be noted that other forms of social and cultural achievements of society also require improved administrative management of them, taking into account the crisis political and socio-economic situation of Ukraine. The article proposes the following directions for improving management processes for basic socio-cultural forms.

1. Administrative management for the preservation of cultural heritage monuments. The relevance of this issue is due to the following factors: the course towards integration with the states of Europe and the world, the preservation of historical memory and cultural diversity. As Kakiuchi E. nicely put, cultural heritage is the result of the work of our predecessors, which provides the foundations of social identity. It should be noted that cultural heritage should not only be protected but also used as an incubator for new cultural creativity. Prerequisites for the successful protection of heritage should be laid at all stages of cultural and general human education. Thus, the main proposal to improve this element of socio-cultural forms is its implementation at several levels at the same time: in international cooperation; within the framework of state protection of historical and cultural monuments; in the practical activities of administrative management bodies. To implement these activities, it is proposed to create a National Heritage Board, the basis of which should be the establishment of standards for the protection and preservation of cultural heritage, raising public awareness on this issue, which will provide the prospect of preserving cultural monuments for future generations under the strategy of sustainable development.

2. Administrative management in the theatre sector. The problem of administrative management in the theatre sector is relevant not only in terms of the role of theater in the spiritual formation of man and his influence on society but also in terms of the growth of the potential of this cultural sector, which has a proportionally small audience to the population of the country. Proposals for improving administrative management in the theatre sector are shown in Figure 1. 


\section{FIGURE 1 \\ IMPROVEMENT OF ADMINISTRATIVE MANAGEMENT IN THE THEATER SECTOR AND EXPECTED CHANGES AFTER THE TRANSFORMATION}

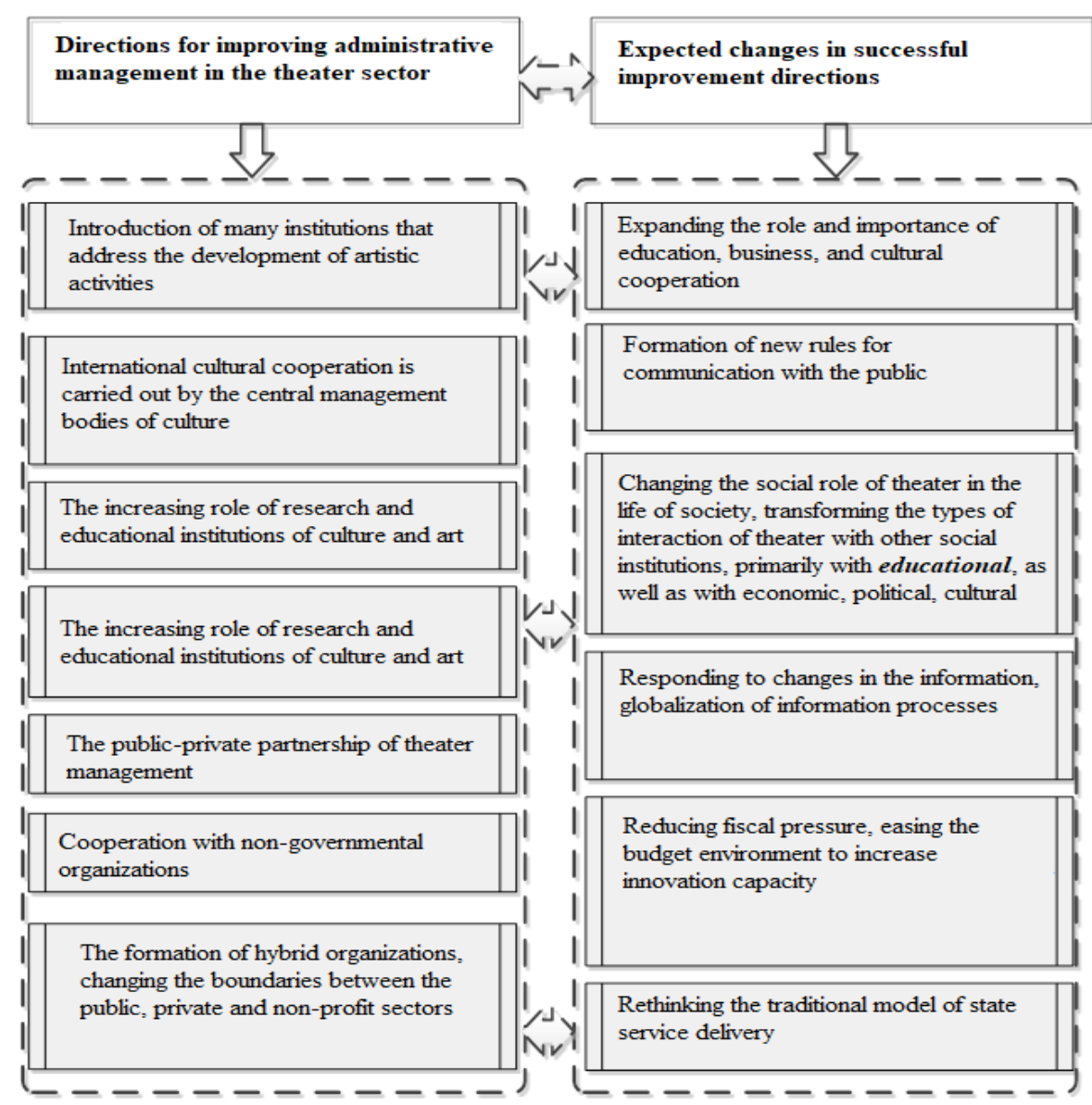

3. Library development administrative management. As foreign experience shows, it is libraries today that are assigned the main role in the development of educational information and cultural activities of the society. They are the main link in carrying out the functions and tasks of educating and training society, preserving its traditions, forming a strong scientific, educational, and cultural state, etc. Particular emphasis is placed on the transfer of administrative management functions in the library business to municipal authorities, that is, the number of libraries at the local and regional levels is growing. An important aspect that is noted in foreign practice is that they become not "places for reading", but full-fledged cultural centers, combine a large number of educational, scientific, and cultural services in which projects are developed and creative forms of work are introduced.

Unfortunately, the situation with the development of librarianship in Ukraine is quite changeable. Therefore, the authors suggested the main proposals for improving the management of this socio-cultural form in Ukraine in the short and long term:

- development and implementation of a program to provide educational institutions with digitized library funds, the creation of high-quality electronic libraries;

- establishment of universal and effective mechanisms for financial support, both from state and municipal authorities and educational institutions and private entrepreneurs;

- abandoning centralized library management or reducing dependency; 
- creation of a system for monitoring the library branch of the country using modern innovative information technologies;

- introduction of control over compliance of the library with the needs of the territorial community;

- development of a library modernization program, which should include three main points: modernization of buildings, modernization of funds, and computer modernization;

- inclusion in libraries of an information center for people with visual and hearing impairments.

Having considered the three main elements of socio-cultural forms, it can be concluded that education a unifying element in all its forms. Intersectoral and international cooperation between cultural and educational institutions, as experts say, can help further expand the potential of the cultural sector. Effective administrative management of the socio-cultural network is considered valid both in small, provincial cities and at the state level as a whole, and can contribute to the educational and cultural attractiveness of lesserknown cities.

\section{THE CONCEPT OF "EDUCATION" AND ITS MAIN CHARACTERISTICS}

According to the Law of Ukraine "On Education" and our own research, the category "education" can be defined as a focused cognitive activity of society, which is aimed at obtaining new knowledge, ability and skills and/or improving them in a changing present. Thus, the process and result of a person's study and mastery of the system of scientific knowledge, practical ability and skills makes it possible to develop his mental, cognitive and creative activities, moral and aesthetic culture, which together determine the socio-cultural personality, individual identity of a person, which in turn allows the development of the whole range of socio-cultural forms with the possibility of their constant improvement. The social challenges of today actualize the need for further improvement of education systems. For this purpose it is necessary to identify the main problems of educational system development management in Ukraine:

- nonconformity of quality and content of education with the current needs of modern society and development of the national economy;

- uneven quality of provision of educational services in the regions of Ukraine;

- lack of mechanisms to implement an effective system of social and cultural development of children and young people;

- inadequate funding and technical and material support for educational institutions;

- insufficient granting of autonomy and ineffective administrative management of education;

- deterioration of the staff of education workers, outflow of qualified personnel abroad;

- the general low prestige of the work of an preschool teacher, education specialist and professor, low wages, lack of adequate motivational mechanisms;

- a little integration of Ukrainian education into the world and European educational and scientific space;

- the existence of misuse of funds by management in the education system, corruption and improper use of the premises of educational institutions of Ukraine;

- almost total lack of effective mechanisms of employment of graduates of higher educational institutions, insufficient state protection of young scientists and specialists;

- ineffective national monitoring and comntrol of the quality of education at all levels of its implementation.

Thus, the above number of problems creates the prerequisites for development a step-by-step process of improving the education management of Ukraine on the basis of continuity, from the pre-school level to the level of higher educational and scientific institutions (Figure 2). As shown in Figure 2, all stages of the process of improving the education management in Ukraine are, on the one hand, autonomous and can be carried out independently of other stages, on the other hand, they are interconnected by the general education system. It should also be noted that the successful modernization of the education system of 
Ukraine should be based on the following principles specific to this socio-cultural form, namely: priority of humanism; democracy and freedom of choice; promoting tolerance; cultivation of universal values.

\section{FIGURE 2 \\ STAGES OF IMPROVEMENT OF THE EDUCATION MANAGEMENT PROCESS OF UKRAINE ON THE BASIS OF CONTINUITY}

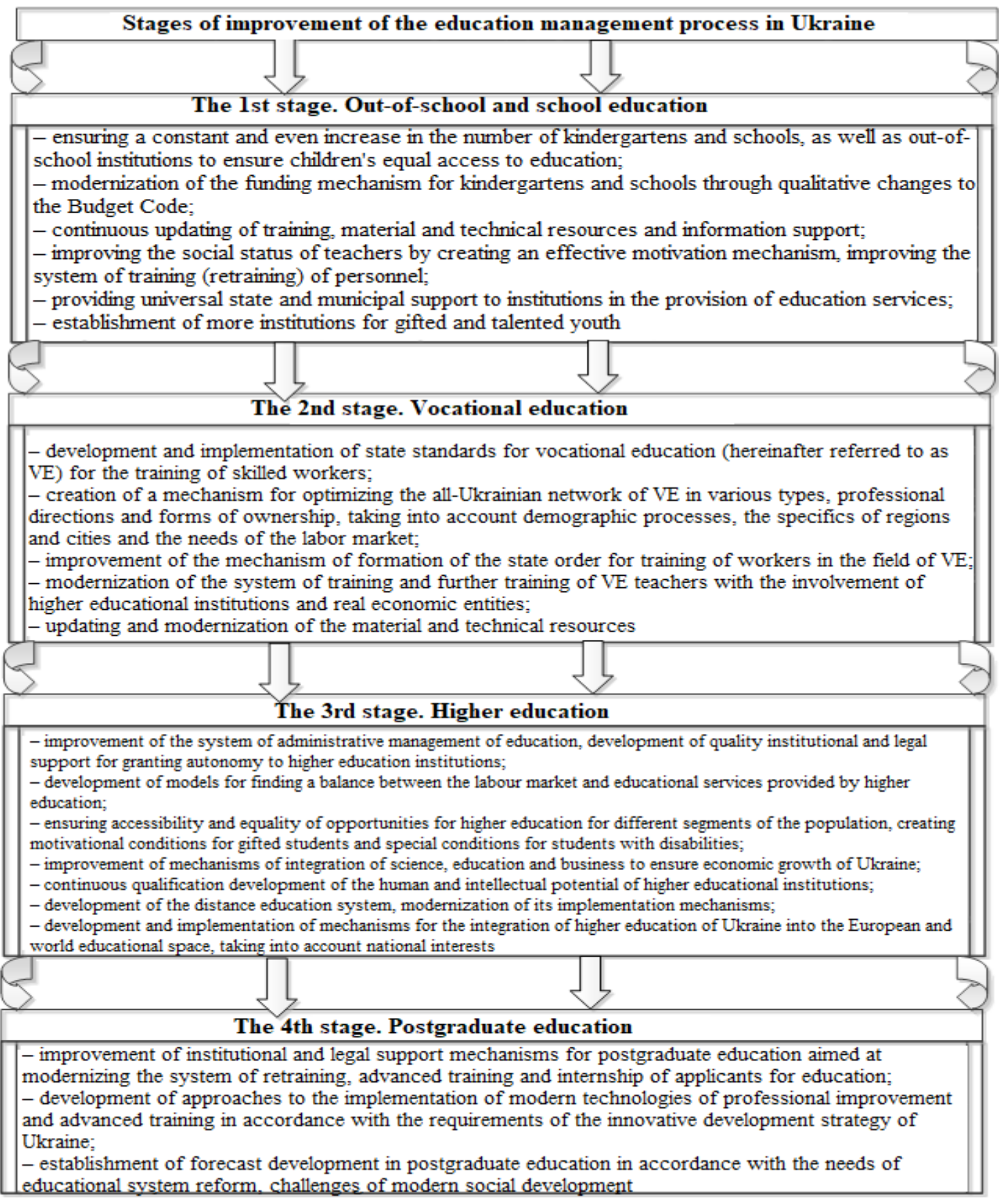

Source: developed by the author

The success of improving the process of education management in Ukraine on the basis of continuity (Figure 2) cannot be achieved without modernizing its administrative management system. Thus, 
administrative management should be carried out on the basis of innovative strategies in accordance with the principles of sustainable development by creating the latest systems of educational projects and monitoring, developing a model of public administration, strengthening the role and interaction of educational policy actors based on the provision that the individual, society and the state are fully equal actors and partners. On the basis of this, a complex of measures is proposed to improve the administrative management of education in order to ensure the creation of a flexible, focused, effective system, a focus on meeting the needs of the country and the needs of the individual:

- modernization of administrative structures, creation of conditions for decentralization of education management by redistribution of powers between state and municipal education management bodies and governing bodies of educational institutions;

- change the procedure for appointing heads of educational institutions and educational management bodies through depoliticization and transparent competition;

- development of a system of measures to establish an effective system of administrative management based on an adequate combination of autonomy with "soft" state and municipal regulation;

- development and implementation of various models of state-public partnership in education;

- reducing bureaucratic processes by improving the mechanism of inspections and reporting by educational institutions;

- attraction and/or training of qualified managers in the educational branch, who can make effective and not always obvious management decisions in the context of the crisis state of Ukraine using the available prospective resources;

- introduction of innovative forms of theoretical and practical training of education managers and scientific methodological services;

- development of improved mechanisms for interaction between the administrative management authorities of education and other actors of this socio-cultural form;

- formation of innovative approaches to improvement of certain subsystems of education (organizational, institutional, instrumental, financial, scientific methodological, etc.);

- creation of opportunities to expand the quality of personnel by attracting specialists with practical experience and introducing them into the staff of educational institutions (official employment);

- development of an automated education management system with the possibility of using modern forms of remote control in conditions of force majeure.

Therefore, with the successful and balanced implementation of the above measures to improve the administrative management of education, it is possible to obtain a modern effective world-class education system that will ensure the human and scientific and technical potential of the national economy, satisfy the needs of society for socio-cultural development, give an impetus to the acceleration of the development of other socio-cultural forms and take a worthy place in the national development strategy of Ukraine as a strong, independent and competitive state.

\section{CONCLUSIONS}

A study of the processes of improving the administrative management of socio-cultural forms in the conditions of a sustainable vector of education development in Ukraine are conducted int the article and obtained the following theoretical, methodological, and practical results:

1. The essence of the concept of "administrative management" for the needs of research on sociocultural forms has been clarified - this is a systematic, organized, administrative activity of state and municipal authorities regulated by laws and regulatory acts, which is aimed at supporting, improving and developing the organizational structure of socio-cultural forms, planning, preparing, forming and implementing the necessary management decisions by the introduction of the documentary, information, personnel and psychological support for their 
functioning to achieve public interest goals and tasks in the educational, cultural and scientific sphere.

2. The definition of the category "socio-cultural forms" in the context of sustainable development is defined as the embodiment of a complex of material and spiritual values, which reflect the constant creative activity of society in the development of the environment, in the course of historical development, and the coverage of the nature of human life through research by addressing its individual spheres, namely, educational, artistic, religious, scientific, political, moral and legal, etc.

3. The main elements of socio-cultural forms are systematized, namely, the preservation of cultural heritage monuments, the theatre sector, and the development of librarianship. Directions and measures have been developed to improve the administrative management of these elements and emphasis has been placed on the relationship between their development and the education system of Ukraine.

4. The importance of effective administrative management of education for the sustainable development of other socio-cultural forms has been proved and it has been found that it provides the basis for the introduction of effective measures to improve specific socio-cultural forms. Intersectoral and international cooperation between cultural and educational institutions can help to further expand the potential of the socio-cultural sector of Ukraine.

5. The main problems of the development of the higher education system in Ukraine, which create the prerequisites for building a step-by-step process of improving the education management of Ukraine on the basis of continuity, from the preschool level to the level of higher educational and scientific institutions, have been analyzed. The specific principles of education management of Ukraine (priority of humanism, democracy, and freedom of choice - the education of tolerance - the promoting of universal human values) on which this system is based are defined. As the main result of the study, the article proposed a complex of measures to improve the administrative management of education in order to ensure the creation of a flexible, focused, effective system, a focus on meeting the needs of the country and the needs of the individual. It was concluded that with the successful and balanced implementation of the above-mentioned measures, it is possible to obtain a modern effective system of world-class education, which will ensure the personnel and scientific-technical potential of the national economy, satisfy the needs of society in socio-cultural development, give an impetus to the acceleration of the development of other socio-cultural forms and take a worthy place in the national development strategy of Ukraine as a strong, independent and competitive state.

\section{REFERENCES}

Andrieiev, A.V. (2015). The field of education as an object of public administration. Scientific Bulletin of Dnipropetrovsk State University of Internal Affairs, 3, 146-151.

Burmaka, T., Orlova, N., Nepomnyashchyy, O., Melnykovych, O., Medvedchuk, O., \& Lahunova, I. (2020). Social Investment as a Tool of Corporate Social Responsibility Realization in Europe. In Education Excellence and Innovation Management: A 2025 Vision to Sustain Economic Development during Global Challenges: Materials of the 35th IBIMA conference (pp. 1015110162). Seville, Spain.

Dallaire, G., \& Colbert, F. (2012). Sustainable Development and Cultural Policy. ENCATC Journal of Cultural Management and Policy, 2(1), 6-11.

Diegtiar, O.A., Orlova, N.S., Kozureva, O.V., Shapovalova, A.M., \& Prykazka, S.I. (2019). Financial capacity of territorial communities: european experience and Ukrainian case. Collection of Scientific Works 'Financial and Credit Activity: Problems of Theory and Practice', 4(31), 516526. Retrieved from http://fkd.org.ua/issue/view/11616

Dombrovska, S.M. (2013). Modern technologies of introduction of innovative state mechanisms of reforming the education system in Ukraine. University Scientific Notes, 2(46), 5-11. 
Gacim, A., Drissi, H., \& Azzouazi, M. (2018). How can the information system be directed to contribute to the overall performance of administrations status of moroccan universities. Periodicals of Engineering and Natural Sciences, 6(2), 356-359.

Hlushchenko, N.V. (2021). Modern issues of administrative law. Legal Horizons, 14(2), 124-129.

Kakiuchi, E. (2014). Cultural heritage protection system in Japan: Current issues and prospects for the future. GRIPS Discussion Paper. Retrieved from http://www.grips.ac.jp/r-center/wpcontent/uploads/14-10.pdf

Karabin, T.O. (2016). Distribution of powers of public administration. Uzhhorod: Hrazhda.

Kolesnykova, K.O. (2013). Public administration in Ukraine: A review of literature sources. Theory and Practice of Public Administration, 3(42), 8. Retrieved from http://www.kbuapa.kharkov.ua/ebook/tpdu/2013-3/index.html

Kolpakov, V.K. (2011). Administrative and legal relations: An alternative view. Development strategy of Ukraine. Economics, Sociology, Law, 1(4), 210-212.

Korzhenko, V.V., \& Meltiukhova, N.M. (2011). Public administration in Ukraine. Kharkiv: Mahistr.

Kozhevnikova, A.V., \& Merkulova, N.V. (2020). Fundamentals of socio- cultural environment in managing the development of multicultural competence of teachers. Scientific Bulletin of Mukachevo State University. Series "Pedagogy and Psychology", 6(2), 83-91.

Kulakova, N.V. (2015). Genesis of international legislation on the protection of cultural heritage sites. Law and Society, 2, 219-223.

Law of Ukraine No. 2145-VIII “On Higher Education”. (2017, September). Retrieved from https://zakon.rada.gov.ua/laws/show/2145-19\#Text

Lelechenko, A.P., Diegtiar O.A., Lebedinska, O.Y., Derun, T.M., \& Berdanova, O.V. (2020). Mechanisms of inter-state communications for solving sustainable development problems. Asia Life Sciences, 29(2), 1-9.

Melnyk, R.S. (2013). The category of 'public administration' in a new interpretation. Administrative Law and Process, 1, 8-14.

Mishchenko, V.A., Lerner, Yu.I., Gevorkyan, A.Yu., \& Mordovtsev, O.S. (2018). Theoretical basis for hanging the quality of higher economic education in Ukraine Kharkiv: TOV "Planeta-Prynt".

Muthu, M. (2013). Resource SharinglnLibraries: A Vital Role of Consortia. International Research: Journal of Library \& Information Science, 3(1), 210-225.

Nepomnyashchyy, O.M., Marusheva, O.A., Prav, Yu.H., Medvedchuk, O.V., \& Lahunova, I.A. (2021). Certain aspects of the system of public administration of universities: World practices and the Ukrainian dimension. Journal of the National Academy of Legal Sciences of Ukraine, 28(1), 99105.

Oliinyk, V.V., Malets, O.O., \& Kukharchuk, O.S. (2019). Problems and perspectives of implementation of modern methods of teaching philosophy in higher education in Ukraine. Scientific Bulletin of Mukachevo State University. Series "Economics", 2(12), 130-134.

Ovdiuk, O. (2020). Formation technologies of the economic mechanism of management decision making. Scientific Horizons, 8(93), 65-71.

Pukhtetska, A. (2010). European administrative space and the rule of law. Kyiv: Yurydychna dumka.

Romanenko, Y. (2016). Place and role of communication in public policy. Actual Problems of Economics, 176(2), 25-31.

Semenchuk, T.B. (2013). The essence of the category of 'public administration' and the prerequisites for its formation. Bulletin of Transport Economics and Industry, 42, 385-390.

Strategy for the development of higher education in Ukraine for 2021-2031. (2020). Retrieved from https://mon.gov.ua/storage/app/media/rizne/2020/09/25/rozvitku-vishchoi-osviti-v-ukraini-02-102020.pdf

Wierenga, S.J. (2021). Content matters: An alternative view on organisational change. International Journal of Learning and Change, 13(6), 590-608.

Yuksel, S.Y. (2021). The problem of subjectivity of values in the search for a universal environmental ethics. Heritage and Sustainable Development, 3(1), 53-57. 